\title{
The Regulation of Public Institution Insolvency in Hungary
}

\begin{abstract}
In the Hungarian legal system-after 50 years-, formerly known legal institutions (such as self-governments, private companies, public institutions) reappeared. These legal institutions are independent of the state, they have their own revenues and properties. Thus the possibility of their insolvency was brought up naturally. The Hungarian legal system does not provide an unambiguous definition of public institution. However, with an eye to foreign legal solutions and the Hungarian specialities, we can formulate the concept of public institution which includes organs that are actually separated from the state, that have autonomy, legal personality, independent budget, their own booking (accounting), and that perform tasks of public utility. These criteria are met by three types of organs: selfgovernments, public bodies, public funds. However, legal regulations concerning these types are not homogeneous. After 1990, when public institutions were established, the state drew back from several public functions and has striven to withdraw itself from the responsibility for inadequate financial administration ever since.
\end{abstract}

Keywords: insolvency, public institution, self-government, liquidation

\section{Introduction}

From time to time the natural (peaceful) development of Hungary's legal system was interrupted by the conquests of external forces (the Turkish Empire, the Habsburg Empire, and the Soviet Union). Due to these influences the homogeneity of our legal system that was built on the Roman law ceased to exist as well from time to time.

This statement is especially true for the period of 1945-1996 when Hungary was put into the zone of interest of and under the authority and guardianship of the Soviet Union-based on the agreement made between the winning powers of World War II in Jalta. The Constitution declared as Law No. XX in 1949 made it clear that Hungary had come off the course of civil society abandoning the multi-party system, the division of powers and the equality

\footnotetext{
*Lecturer, University of Miskolc, Miskolc-Egyetemváros, H-3515 Miskolc, Hungary.

Fax: (36 46) 565-111; E-mail: jogtoa@gold.uni-miskolc.hu
} 
of the forms of ownership. Instead Hungary started to build a so called socialist system of society that did not recognize the basic values of civil society. It was built on the one-party system, the unity of powers, and the exclusiveness and extreme priority of state property. The emphasis of these principles of course resulted in the rejection of market laws and the creation of the state planned economy. During the period of socialism the state took all the public functions, furthermore, it was the only party in the economy through its companies. All this resulted in an extremely centralized central and local administration (Soviet pattern: the council system) where there was no private property, nor autonomy. Some changes occurred in this social and economic system beginning in the 1970s. Private enterprises and companies appeared in Hungary, the force sticking the local administration to the central authority lessened.

This was the social and economic environment the legal system was adapted to. The socialist model meant that a series of institutions (economic companies, local self-governments, public boards, and public foundations) that had existed before 1945 had vanished from our legal system. At the same time a series of institutions had been established according to the Soviet pattern (state companies, councils). The speed of change in the legal system is properly demonstrated by the fact that 13769 measures were accepted (acts, government regulations, ministry regulations)! Due to the omnipotence of the state the question of insolvency was not raised at all (not even in the economy!), nor was the transfer of particular public tasks to private organizations.

\section{The effects of the political changes in 1989-1990}

As it is widely known, the collapse of the Soviet Union brought freedom to the Central European countries (Hungary as well) that belonged to the Soviet zone of power according to the above mentioned agreement made in Jalta. The people's republic ceased to exist in Hungary in the fall of 1989 and Hungary became a republic. The Constitution has been considerably amended. The Constitution now declares that Hungary is an independent state, it is a democratic country based on the multi-party system, the division of powers, the equality of forms of ownership and the market economy. According to these principles a proper state organization has been established that meets the requirements of constitutionality. New organizations have been created (the Constitutional Court, the State Audit Office, local selfgovernments, ombudsman etc.), and the powers and tasks of the institutions that had operated earlier (the Parliament, the Government, courts etc.) have changed. A radical transformation of the legal system has begun. 
(For the sake of historical fidelity it must be recorded that the need to change the state organization and the legal system could be strongly felt in the middle of and at the end of 1980s. The transformation of the legal system and the preparation for a radical transformation already started in the mid1980s. This is demonstrated by the fact that $47 \%$ of the 1835 valid acts and $73 \%$ of the 2082 ministry regulations were canceled!)

I would like to emphasize only those laws-besides the modification of the Constitution-that are most important in the subject regarding the radical transformation and renewal of the legal system:

- Act No. VI of 1988 on the companies,

- Act No. II of 1991 on the procedure of bankruptcy, liquidation and final settlement,

- Act No. LXV of 1990 on the local self-governments,

- Act No. XXV of 1996 on the settlement procedures of local selfgovernment debts,

- Act No. XLII of 1993 on the amendment of the Civil Code (Law No. IV of 1959),

- Act No. XXXVIII of 1992 on the public finances,

- Act No. CLVI of 1997 on public utility organizations,

- Act No. XL of 1994 on the Hungarian Academy of Science,

- Act No. II of 1989 on the right of association,

- Act No. CXXI of 1999 on the economic chambers,

- Act No. XXXVIII of 1989 on the State Audit Office.

These laws mark the legal frames of creation, operation and windingup of public institutions not owned by the state, including the procedures to be followed in case of insolvency.

The radical transformation of the Hungarian legal system is proven by the fact that Hungary has closed 22 chapters in 2001 in the negotiations on the accession to the European Union and the country has a real chance to close the negotiations completely by the end of 2002. The Hungarian legal system is practically compatible with the Union's legal system, the "acquis communautaire".

\section{The sphere of public institutions in the Hungarian legal system}

To define the sphere of public institutions one must start from the concept of public tasks. In my standpoint public tasks, in a vague sense, are all those tasks that must be carried out by the state as a whole entity. This includes legislation, executive tasks and jurisdiction as well. In a narrow sense 
public tasks are those tasks that must be carried out by the executive branch of power according to the laws.

The state (the Parliament) has the public tasks of the narrow sense carried out by the government, ministries and the national central authorities and the local organizations of the latter. Also the state orders the local selfgovernments to execute some of these tasks or creates organizations that carry out public tasks independently but supervised by the state (public boards and foundations). In Hungary the organizations belonging to the first two categories (state administrative organizations and local selfgovernments) make up the executive branch of power and they represent the organizational system of the Hungarian administration together.

The local self-governments can take other public tasks besides those prescribed by the act. They can do this with two restrictions: 1 . the tasks is not ordered to be done by another organization according to the law, 2 . the performance of these tasks does not endanger the performance of the mandatory tasks. The local self-governments can establish public foundations, public utility companies and even economic companies to carry out the tasks of the local self-government.

In my standpoint due to the above mentioned facts it is necessary to give a definition of public institutions in a vague and a narrow sense as well. In a vague sense public institutions are all those state and non-state organizations that carry out public tasks (including the state administrative organizations as well). In a narrow sense public institutions are those that are really separated from the state and that carry out public tasks as independent legal entities with their own budget and accountancy. In my standpoint the following organizations belong to this category: local self-governments, public boards and public foundations.

The present review introduces the public institutions according to the narrow sense, concentrating on their management and insolvency and trying to answer the questions given by Professor Knapp who made the main review.

\section{The viewpoints of the main review}

The viewpoints of examination given by Professor Blaise Knapp raise the following questions regarding the insolvency of Hungarian public institutions:

1. What kind of sources of finance do these organizations have based on the law or whether they are entitled to take loans only as accepted by practice?

2. Whether the loans taken by these organizations are subjected to special administrative procedures or to the general rules of taking loans? 
3. Whether it is necessary to provide a deposit toward the creditors (if yes, what kind of deposit)?

4. Whether there is a rule of law regarding the highest possible limit of indebtedness. Or this limit is defined by the supervising organization or by the principles developed during the operation. i.e. whether the highest possible limit of debt is determined by the general principles of "ordinary" management (balance of the budget)?

5. Whether there is a rule of law for the supervising organizations to make steps and inspections to prevent these institutions from getting into debt (internal audition, investigation of external organizations, Audit Office, Financial Supervising Body)?

6. How to define the concepts of indebtedness and that of insolvency? Should the public institution exceed a limit defined by law or exceed the ability to pay back the credits and interests? Or it does not have any more chance to take new credits, nor to extend the term of earlier credits? Or does insolvency mean a permanent state of indebtedness?

7. Who (which person or organization) should make steps in case of permanent insolvency and what kind of steps should be made to end insolvency?

a) Should this be done by the public institution involved? (For example it increases the incomes by imposing more tax or by selling means or by reducing expenses or services or by reducing the quality of these or by privatizing the public services?)

b) Should it be done by the supervising organizations? (Are there such organizations and what kind of authority they have?)

c) Should it be done by the creditors? (who go to court)

Do these possibilities complement or exclude one another?

8. Whether the creditors can ask for liquidation or termination of the public institution from the court? If not, what kind of possibilities do the creditors have?

a) Selling the existing goods,

b) giving an extended deadline for the payback of credit and its interests,

c) giving up the claim,

d) other means.

9. Whether the state is responsible for the debts of the public institutions without any legal basis and if yes, this responsibility is universal or complementary (secondary)? Can one make difference between the public institutions as legal entities or institutions having a budget separated from that of the state?

10. Can those creditors whose demands have not been met sue the organizations doing external inspection or the state because they have not 
controlled the management (accountancy, budget) of the public institution properly?

11. Whether the situation is different when the state gives the task to a private organization (state-owned corporation or joint venture)?

12. Can criminal procedures be started against those persons who are responsible for the state of being in debt?

In Chapter 2 I referred to the fact that the concept of public institution is not homogenous, it is a collective concept for different organizations. The order of establishment, management, control and termination for the different types of public institutions is not uniform, it is different for each type. This means I need to answer all the 12 questions for each type of public institutions! Before answering the questions, however, I need to introduce the appropriate part of the Civil Code on legal entities (Chapter VI) to make understanding easier. Also I need to introduce the most important appropriate parts of the Law on public finances (Act No. XXXVIII of 1992). The latter is important because the assets of the local self-governments and the assets transferred to public bodies belong to public finances.

\section{The appropriate and most important rules of the Civil Code and the Act of public finances}

According to the Civil Code a legal entity is able and if the Act does not order otherwise, this ability extends to all those rights and responsibilities that can be connected not only people. The Act has an independent chapter on the different rules regarding the different types of legal entities. The following legal entities were named:

1. state-owned companies,

2.trusts,

3. other state-owned organizations,

4. budget financed organizations,

5.co-operatives,

6.economic companies with legal entity,

7.public utility companies,

8. associations,

9. public corporations,

10. companies of some legal entities,

11. affiliated companies,

12. foundations, 
13. public foundations,

14. syndicates.

Due to the conceptual features of public institutions mentioned above, types 4, 9 and 13 are important for us. Type 4 is important because-as we will see later-the institutions established by local authorities and public corporations (schools, medical and social institutions, cultural institutions etc.) are budget financed organizations. The Act declares that the state is a legal entity as the subject of the legal relationship concerning assets. Finally I also need to refer to the fact that the local self-government is a legal entity too according to the Act of local self-governments. As regards the Act of public finances, the following features need to be emphasized:

The public finances is a system of the central government, the separated state funds, the local self-governments and the Social Security that performs and finances state tasks. This system has appropriate sub-systems: the budgets of the central government, the state funds, the local self-governments and the Social Security. These budgets together make up the national budget.

The budget of each sub-system is a financial plan that contains the approved expenses (as an estimate) for the performance of the tasks for the given period and also the expected incomes (as incomes).

The state performs the tasks belonging to the public finances through the so called budget organizations or it transfers the coverage partly or completely at the same time it transfers the task to the local self-governments, public corporations or public foundations.

A budget organization is a legal entity that is part of the public finances and performs tasks that satisfy social common needs as basic tasks. They are not for gaining profit and they operate according to the liabilities recorded in the founding charter or document with the recorded professional and economic supervision and sphere of jurisdiction and operation. The types of budget organizations are the following:

1. central budget organizations,

2. local self-government's budget organizations,

3. public corporation's budget organizations,

4. society inowance budget organizations.

The Parliament, the Government, the leader of the organization supervising the budget section, the local self-governments and the public corporations can establish a budget organization by law or foundation document. Then the budget organization is registered by the Minister of Finances.

A central budget organization cannot establish a foundation, but it can establish so called social organizations with the permission of the Govern- 
ment. To establish an economic company or to optain shaire in economic companies the central budget organization should have a permission from the organization supervising the given budget section with the consent of the Minister of Finances.

A local self-government or public corporation's budget organization can establish a social organization or a foundation only with the permission of the local self-government or the public body. The local selfgovernment budget organization can establish an economic company with the permission of the local self-government and it can optain shaire in such a company.

It is a serious restriction to state that a budget financed organization can take part in an economic company where its liability does not exceed the extent of its contribution in assets. The budget financed organization is subjected to manage within the estimate. It cannot loan money, cannot be a guarantor, cannot buy bonds - except the bonds that represent its share in the economic company, it cannot draw nor accept bills of exchange, cannot issue bonds. The budget financed organization has liabilities exceeding its budget. In this case the organization establishing the budget financed organization (the state, the local self-government, the public body or the Social Security) must hold on. This liability is valid in the cases of compensation, pay-off and making amends and also in cases when the organization took liabilities toward a well-meaning third party.

The law on public finances states that the exclusive purpose of the assets belonging to the sub-systems of public finances is the service of public interest. The Parliament makes arrangements regarding these assets by law and it should manage these assets with responsibility and according to the purpose. The treasury assets, the assets of local self-government's and the society inowance belong to the public finances. Also the assets transferred to public corporations by law belong to the public finances too. The Parliament controls the management with the assets belonging to the public finances through the State Audit Office. The assets connected to the subsystem of public finances-beyond a value limit determined by law or local self-government resolution-can be sold, its right to utilization can be passed only to those who make the best offer. This is done through a public tender. The proprietary and management rights can be transferred free of charge, the demands can be waived only in the cases and in the ways determined by law or by local self-government resolutions. 


\section{The first type of public institutions: the local self-government}

\subsection{General informations on local self-governments}

As I mentioned in the Introduction, the local self-governments are oldnew institutions in the Republic of Hungary, because they had been operating before 1950 at a local and regional level, which was similar to the Western European pattern. In 1950 the councils took the places of these institutions-according to the Soviet pattern. Since the councils did not have autonomy nor own property, and they were supported only from the central budget, the problem of insolvency never came up. One of the determining changes in the state administration during the political changes of 1989-1990-as I also mentioned-was the cancellation of the council system and the reconstruction of the local self-government system.

According to Article 41 of the Constitution the territory of the Republic of Hungary is divided into a capital city, 19 counties, 260 towns and 2850 villages. The capital city consists of 23 districts.

Article 42 of the Constitution states that the citizens of the capital city and its districts, the counties, the towns and the villages have the right for local self-government. This liberal regulation means that practically all towns and villages have operating local self-governments and the number of these is about 3200 !

The local self-government provides public services and manages local public affairs. It has its own legal entity, it has own property and incomes. It manages independently its own property, its incomes and expenses. It carries out its mandatory and voluntary tasks from its own budget. The budget of local self-governments is an organic part of the public finances. The budget of local self-government is separated from the public finances but they are closely related to each other because of the state subsidies and budget connections. The local self-government can freely establish associations with other local self-governments and can have enterprises for its own responsibility. The enterprise cannot endanger the mandatory tasks. The local self-government can take part only in such enterprises where its liability cannot exceed the extent of its support in assets. A further restriction regarding enterprises is that the so called basic assets (public utilities, public buildings owned by the local self-government, streets, squares) of the local self-government current or can be current only with restrictions. 


\subsection{Answers to the raised questions}

Ad 1. The income of local self-government, taking out credits The local self-government carries out the mandatory tasks regulated by law, the voluntary tasks via its own organization as a budget financed organization, or by establishing public foundations, public utility companies, economic companies or by concluding contracts with other management organizations (concessions, services, purchase etc.). Most tasks are practically carried out by the own organizations, but the other ways mentioned above are becoming widespread too. The local self-government chooses the forms of management freely adjusting to the type of the task. Also it creates the rules of concern within the frames of law. The necessary resources to carry out the tasks are taken from the incomes that make up the income part of the local selfgovernment budget.

The incomes are the following:

\section{1.) Own incomes:}

a) Local taxes regulated by law. These taxes are determined and imposed in local self-government regulations (The law permits the local selfgovernment to impose asset type taxes, communal taxes and local trade taxes),

b) profit, interest and rental coming from own activities, enterprises and returns of local self-government assets,

c) a determined portion of duties,

d) received financial means (e.g. from ministries or separated state funds),

e) a determined portion from fines of environmental protection and protection of monuments,

f) incomes from the utilization of hunting rights that belong to the local self-government,

g) other own incomes.

2. Central taxes given over by the Parliament:

a) a determined portion of income taxes collected from individuals (The rate was 100\% in 1990, 50\% in 1991 and 1992, 20\% in 1998 and 5\% in 2000),

b) other divided taxes.

3. The normative budget contribution provided by the Parliament:

(About two third of the state subsidies go to the local self-governments in this way!) The local self-government can have the normative budget contribution in two ways. The normative division of the financial means coming from the central budget cannot handle the local self-governments 
that differ from the average, so the law ensures additional subsidies as well. These are the following: subsidies dedicated to special goals, addressed subsidies and additional state subsidies. These are further claims for further incomes.

4. Subsidies dedicated to special goals:

The Parliament determines the socially relevant goals. The budget determines the sphere of subsidized causes, the order of priority for these causes, the amount and conditions of subsidies. The state wants to orient the local self-governments to get them to achieve important community goals (sewage network, construction of public facilities). The goal subsidy can be used only for the given goal.

5. Addressed subsidies:

The Parliament provides this for the local self-governments to finance some investments demanding major expenses. Can be used only for the given goal.

6. Additional state subsidies:

The Parliament provides this kind of subsidies for local self-governments who do not have their own sufficient resources. The amount is regulated in the law on State budget. (The total amount was about 10 billion HUF in 2000.) The purpose of additional subsidies is to enable local self-governments with insufficient resources to operate or to get them to operate, so that they could carry out their basic tasks even if they do not have sufficient own resources. The Parliament decides on the amount and conditions of subsidies in the budget law.

Summary: regarding the incomes and the financial conditions, the local self-governments can manage about one quarter of the financial means centralized and re-distributed at the public finances. The current yearly expenses are around 1300 billion HUF, the value of their assets is beyond 2000 billion HUF. During the past 10 years the portion of incomes coming from the central budget decreased gradually (from 50\% to 30\%) among all available incomes. Meanwhile the portion of own incomes has been increasing (especially the local taxes). The local taxes were only $2.4 \%$ of the local self-government incomes in 1991, while in 1999 it was $12.9 \%$. Of course this is still far behind the $52.8 \%$ of Switzerland, the $49.8 \%$ of Norway and the $34.9 \%$ of Germany.

The question of taking out credits

The Act on local self-governments also regulates the major questions of local self-government management besides the income claims. The Act states that the local self-government: 
a) can establish a public foundation and can take on public tasks,

b) can take out credit and issue bonds, but cannot use the basic assets and the incomes mentioned under $1 \mathrm{~d}, 2 \mathrm{a}, 3$ and 6 to cover these,

c) decides to deposit the resources not connected to special goals,

d) decides on using other bank services.

It is a major rule to state there is an upper limit for taking on those yearly liabilities that could create debts. This is the so called own current income. This is $70 \%$ of the yearly estimate for the own current income minus the proportional part of the short-term liabilities for a year.

\section{Ad2. The procedure of taking out credits}

I referred to the fact that the law entitles the local self-governments to take out credits and there is no regulation that requires asking for permission. The bank and the local self-government make an agreement regarding the conditions of granting credits.

\section{Ad3. Deposit}

Whether the creditors ask for deposit or not, it is their business, whether the local self-government gives deposit, it is their business. So they have the power of choice in this matter. However, we cannot ignore the fact that there is a restriction: the basic assets and the incomes mentioned under $1 \mathrm{~d}$, 2,3 and 6 cannot be used as deposit.

\section{Ad4. The extent of indebtedness}

The answer is under 1, so there is an upper limit!

\section{Ad5. Control}

The Act on local self-governments states that the representatives of the local self-government are responsible for the safety of management, the mayor is responsible for the regularity. If the local self-government as a legal entity manages with losses, they must bear all the consequences as well. So the state budget is not responsible for the liabilities taken by the local self-government. In case of loss-making management, a debt-arrangement procedure must be carried out. During the procedure the local self-government must stop financing the tasks (except authority tasks and the basic services for citizens) in order to rehabilitate solvency. (This topic will be mentioned later!)

The law on local self-governments puts emphasis on the control over the management. The following major rules are stated:

The State Audit Office controls the management of local self-governments. There is an independent law on the State Audit Office (Act No. XXXVIII 
of 1989). This law states that the State Audit Office is the financial-economic controlling organization of the Parliament. It controls according to expedience, lawfulness and efficiency. The control of local self-governments by the State Audit Office is impeded by the scattered system of local self-governments, since there are nearly 3200 local self-governments, 13,000 local selfgovernment institutions (budget institutions). The State Audit Office practically cannot control these at least once in a quarter of a year due to lack of capacity. The State Audit Office selects the local self-governments to be controlled according to a scientifically developed sample-taking system. In 1999 the Office controlled 802 local self-governments and 1533 institutions.

It is important to emphasize that the financial-economic control of local self-governments is not the monopoly of the State Audit Office, the state created a wide network of internal and external control. The external control can also be done by an independent certified public accountant (CPA) besides the State Audit Office. The audition is extended to the following:

a) the verification of reports, the balance, the yearly report on circulation of money and the statement on results,

b) making statements about the bylaw drafts on the budget and final accounts,

c) analysis of the financial situation.

The employment of a CPA is mandatory for only $30 \%$ of the local selfgovernments: the local self-governments of counties, those of the capital city and the capital city districts and the local self-governments of cities and also those local self-governments where the expenses of the preceding year exceeded 100 million HUF, the local self-government has credit or takes out credit.

The internal control is carried out by the mandatory Financial Committee and the internal auditor whose qualifications are determined by law. Another type of control is the mandatory control of the leaders and the control built in the processes of work and management.

\section{Ad 6. The concepts of indebtedness and insolvency}

The concept of indebtedness is not defined by law, the concept of insolvency can be defined on the basis of the law on debt arrangement procedures (Act No. XXV of 1996). According to this the debt arrangement procedure can be initiated by either the local self-government or the creditor at the competent county court. The procedure can be initiated if the local selfgovernment or its budget financed institution

a) the invoice or notice sent by the creditor has not been disputed nor paid within 60 days after the date of fulfillment, 
b) the debt was not paid against the agreement made at an earlier debt arrangement procedure,

c) the debt toward other sub-systems of the public finances was not paid within 60 days after the receipt of the immediate collection notice.

The result of these conditions is that insolvency means the following: the procedure can be initiated if the above mentioned conditions exist. The insolvency is a relatively permanent condition of being in debt (60 days), but it does not depend on the sum of money. Before starting the debt arrangement procedure the local self-government has a chance to solve the problems itself. Example: reducing expenses, taking out credits, selling real estates, imposing taxes, privatizing public services, however, all these activities have restrictions by law. If the procedure has started, the chances of the local self-government are reduced to those that are regulated by the law on debt arrangement.

\section{Ad7. The question of permanent insolvency}

I have already given a part of the answer in the preceding section and I am giving the other part here according to the following:

The debt arrangement procedure has a dual purpose. The first one is the protection of the local self-governments (and their institutions) and that of the creditors. The second purpose is the rehabilitation of the local selfgovernment's solvency and ability to operate so that they can carry out their public tasks. It is necessary to emphasize that these purposes do not give any reasons to the state to take any responsibility for the local selfgovernments. The court publishes the decision on starting of the debt arrangement procedure in the Company Gazette, the mayor publishes it in two national newspapers with an announcement to the creditors, asking them to announce their claims within 60 days. The court assigns a financial administrator at the starting of the procedure. The mayor is obliged to inform directly the county administration office and the account-keeping bank about the starting of the procedure. After this the bank can charge the account and pay out money only with the financial administrator's countersignature. After the start of the procedure the local self-government cannot make any more decisions on taking extra liabilities concerning assets, cannot establish any enterprises, cannot gain any property in enterprises in a commutative manner, cannot pay out any earlier debts. Except for the regular personal benefits and the expenses according to the crisis budget. The financial administrator registers the creditors who announce their claims, examines their claims and informs them within 15 days whether their claims are acceptable or not. The local self-government is obliged to 
establish a debt arrangement committee within 8 days after the start of the procedure. This committee is entitled to decide on all economic issues, except for the issues that come under the exclusive authority of the board of representatives (personal affairs, making bylaws). The notary compiles a bylaw draft about the crisis budget within 30 days after the start of the procedure. This budget includes exclusively those expenses of services and authority tasks that are listed in the appendix of the law (example: operation of cemeteries, cleaning of public areas, ensuring water supply, street-lighting, operation of kindergartens, schools and health facilities etc.). The local self-government cannot finance such institutes where the capacity is less than $50 \%$.

The debt arrangement committee (which includes the mayor, the notary and the financial administrator) discusses the bylaw draft, then the board of representatives passes it. The board of representatives makes a reorganization program and an agreement resolution. The program describes the economic situation of the local self-government and records the proposals regarding the utilization of assets involved in the debt arrangement and other planned steps (example imposing taxes, increasing taxes, reducing expenses, taking out credits). The agreement resolution lists the creditors into groups. The financial administrator sends the reorganization program and the agreement resolution to the creditors and invites them to a meeting of agreement. Minutes must be kept at the meeting. An agreement can be reached only if more than $50 \%$ of the creditors accepts it and their claims are $2 / 3$ of the whole claim. The financial administrator hands in the document of agreement to the court, which wraps up the procedure and orders the announcement of this in the Company Gazette. At the same time the court relieves the financial administrator of their position. If there is no agreement accepted between the parties, the court orders the division of the assets within 210 days after the start of the procedure. The court orders the division of the assets if:

- the board of representatives is out of operation (due to any reason) or the dissolution of the board has been initiated due to operation against the constitution,

- the board has not accepted the bylaw on the crisis budget,

- the reorganization program and the agreement resolution has not been made, the creditors have not made their own proposal of agreement,

- the court has not accepted the document of agreement handed in by the financial administrator.

The local self-government can carry out the tasks only according to the resolution on the crisis budget until the court divides the assets. The financial administrator determines the forms of carrying out the mandatory tasks in 
a report and determines which properties need to be sold to cover the expenses of these tasks and what central budget subsidies are necessary and also determines which properties can be included in the debt arrangement. The financial administrator sends the report to the creditors and the local self-government. They can make their comments within 15 days at the court. After the assenting decision of the court inures, the financial administrator:

- lists the creditors' claims in 30 days,

- attempts to sell the assets involved in the debt arrangement within 60 days (creditors have pre-emptive right).

After then the court obliges the financial administrator to execute the division of assets, then the court wraps up the procedure and relieves the financial administrator of their position. The law determines a mandatory order of pay-off. Until the first creditors' claims in the order are not paid off, the later creditors are not paid off.

If the local self-government established the conditions of the agreement with the creditors by taking out a credit, the central budget-at requestprovides an interest-free refundable subsidy to pay off that part of the interest that the local self-government does not have coverage for. (About 200 million HUF were available for this purpose in 2000.)

The debt arrangement procedures of local self-governments occur very rarely in Hungary, opposed to the bankruptcy proceedings of companies. At the time of making the law on local self-governments in 1990 and in the following 5 years there was no need to make such a law. The explanation of this situation is that the local self-governments have been managing with responsibility and they rarely have taken on liabilities exceeding their abilities. When in 1995 several local self-governments indicated that their management had become troublesome, the Parliament modified the law on local self-governments (restricted the upper limit of taking on liabilities) and then made the Act No. XXV of 1996 on the debt arrangement procedure of local selfgovernments. In the past years there have been altogether 7 cases when such procedures were executed. In 5 cases agreement was made with the creditors, while in the other two cases the court divided the assets. It is noteworthy that it was not the creditors who initiated the procedures in either case!

Ad8. Can the creditors ask for bankruptcy proceeding, liquidation?

The answer is yes resulting from the facts mentioned above, but the terms of bankruptcy proceeding and liquidation can only be used in case of economic companies. In case of local self-governments-as we could seethe right term is debt arrangement procedure. The creditors can initiate debt arrangement procedures, the experience shows there have been such 
cases so far. The local self-governments Act quickly in case of solvency problems: they try to reduce their expenses, mobilize their assets, take out credits and they try to get the loans rescheduled. It is important to emphasize that there is no possibility of liquidation of local self-governments during debt arrangement procedures!

Ad9. Is the state responsible for the debt?

I have already referred to the fact that in Hungary the local self-governments have autonomy, they are independent legal entities, they have their own properties and they have whole and exclusive responsibility in arranging the local public affairs. The state has no universal, nor secondary responsibility for the possible debts of local self-governments, including the debts local self-government institutions (schools, health facilities etc. as budget financed institutions) too. When the tasks are carried out by not the local self-government's own institutions, or the tasks are transferred to other organizations or the tasks are carried out in form of concessions, the local self-government is not exempted from responsibility of carrying out the tasks. If the contractual partner or the organization entitled to the concession goes bankrupt, this does not concern the local self-government's obligation to carry out the tasks. It is a different matter when the local self-government helps the contractual partner or organization entitled to the concession in case of solvency problems. It is possible for the local self-government to establish an own economic company to carry out the tasks. But this fact does not change what was written earlier, but if the economic company goes bankrupt, the resolutions of the bankruptcy law will be valid. The local self-government (as the owner or founder) has limited liability, as I referred to the fact that the local self-government. cannot be a member with unlimited liability of any economic company.

Ad10. Can those creditors initiate a trial who have not been paid off?

Those creditors who have not been paid off can theoretically initiate a trial against any organization that is entitled to carry out the financial-economic control of the local self-government. (I referred to these organizations under ad5.)

The Civil Code makes compensation possible when someone (or some organization) causes damage illegally. The amount of damage, the illegality and the relationship between the damage and the illegality should be proven by those who have suffered the damage. This is not an easy job. As far as I know, there have been no such trials so far in Hungary, but the theoretical possibility of such trials is not excluded! (The state initiated a similar trial against those world-famous auditing companies that audited Postabank 
and the state claimed for compensation for inappropriate control. This trial is still going on.) I completely exclude the possibility of winning a trial against the state.

Ad11. The question of transferring tasks to private organizations

The state determines the mandatory tasks of local self-governments by law. These tasks are carried out by the own organizations of the local selfgovernment (schools, health and social facilities) or by organizations the tasks have been transferred to (by establishing public utility companies, economic companies or with concessions). As we could see, the successful performance of the tasks is the responsibility of the local self-government and it has full responsibility as well.

There is a theoretical possibility that the state obliges private organizations, public utility companies or economic companies to carry out given public tasks. In this case the state is also exempted from any financial responsibility, because the responsibility as owner can be limited only. However the state is still responsible for carrying out the task. It is possible that the state trusts neither local self-governments nor, but public boards or foundations to carry out public tasks private organizations. I will write about this later.

\section{Ad12 The question of initiating criminal procedures}

The law makes it mandatory for the organizations entitled to control to make reports when they have a suspicion of criminal acts. The creditors do not have this responsibility but they have the possibility to make reports to the authorities. Several criminal acts can occur concerning this area, so the Criminal Code names several types of criminal act when someone is responsible for getting in debt. These are the following:

a) Breach of Trust

That person commits this crime who is trusted to handle foreign property and the person causes financial damage by failing to carry out their liabilities.

b) Negligent Breach of Trust

That person commits it who is trusted to handle or supervise foreign property based on law and the person causes financial damage by failing to carry out or neglecting the responsibilities.

c) Fraud

That person commits it who deceives others to gain illegal causes.

d) Embezzlement

That person commits it who theft foreign property that was trusted to them and they treat that property as if it was their own. 
e) Violation of credit

That person commits it who takes away the coverage of the credit partly or completely or makes it impossible to pay off the creditor from the coverage in any other way.

f) Taking away the coverage of debt

That person commits it who takes away assets that serve as coverage for debt that comes from economic activities and thus makes it impossible to pay off the debt.

g) Unlawful preference of creditors

That person commits it who is aware of their insolvency, gives illegal advantage to one of the creditors to the disadvantage of the rest of the creditors.

h) Bankruptcy

That person commits it who hides or destroys the assets serving as the coverage for insolvency that comes from economic activities or the person makes a false deal or intentionally does loss-making businesses and thus makes it impossible to pay off the creditors.

\section{The second type of public institutions: the public boards}

\subsection{General information on public boards}

The Civil Code records the concept and most important feature of public boards. In this way a public board is a legal entity with self-government and recorded membership whose establishment is regulated by law and that carries out public tasks. The tasks are connected to the members or the activities done by the members. The public board is not established based on the free will of the members (as it is the case with associations), but it is established by law. The Parliament trusts public boards and not public administration organizations to carry out given public tasks. The law can order that some tasks can be carried out exclusively by public boards, on the other hand, some tasks can be carried out only as a member of a public board. The law can determine mandatory tasks for the public board. In this case the codifying organization ensures particular public licenses to the public board that is executed through self-administration. The codifying organization ensures appropriate assets to the public board. The board manages these assets independently, of course under state supervision. The rules valid for the associations are to be applied for public boards. I discussed the law on public finances in Section 4 and I referred to the fact that the assets trusted to public boards belong to public finances. These assets must be managed 
appropriately and with responsibility. This is controlled by the State Audit Office. Public boards are the Hungarian Academy of Sciences, the economic chambers (chambers of commerce and industry, agricultural chambers), professional chambers (medical, pharmacist's and lawyers' chambers) and also mountain municipalities, the Hungarian Board of Standards, the Public Foundation of the Hungarian Television and the Public Foundation of the Hungarian Radio. As the establishment of public boards is ordered by law, there is law for each board. The regulation on the specific tasks, management, incomes, expenses and state supervision of public boards is not uniform due to the separate laws regulating each public board. That is why there is no uniform answer to the 12 questions only generalized answers can be given. I will try to refer to the differences.

\subsection{Answers to the raised questions}

Ad1. The income of public boards, taking out credits

The operational expenses of public boards are generally covered by the following resources:

a) membership fees paid by the members and other fees,

b) sums taken from the central budget,

c) foundation and other contributions,

d) sums won from competitions,

e) sums coming from national or foreign co-operations,

f) income from operation and utilization of assets,

g) other income not forbidden by law.

Taking out credits belongs to the latter category. The state ensured a considerable amount of goods and real estates for the Hungarian Scientific Academy of Sciences in Act No. XL of 1994. These assets ceased to be state assets, so these assets became the property of the Academy. The same can be told about the Hungarian Board of Standards, the Public Foundation of the Hungarian Television and the Public Foundation of the Hungarian Radio. This one-time allocation of assets from the state at the time of the establishment does not mean that these public boards cannot gain any income from other resources mentioned above. The exact amount and type of income is regulated by law in the case of each public board.

\section{Ad2. The procedure of taking out credits}

There is no special, mandatory procedure, the public board and the bank make agreements on the conditions freely. The internal rules of some public boards (Basic Rules) usually record the conditions of taking out credits. 
Ad3. Deposit

There is no mandatory law, so the deposit is a subject of free agreement. Giving deposits can be restricted by the internal rules of the boards.

\section{Ad4. The extent of indebtedness}

There is no law, nor restriction, so this is also a matter of internal regulation. Each board is obliged to carry out the tasks determined by law, so it is obvious that the public board cannot endanger the performance of these tasks. So the extent of indebtedness is regulated by the general principles of "normal management".

\section{Ad5. Control}

There is no specific regulation on control to prevent indebtedness. The state, however, tries to prevent irresponsible management through internal and external control. The forms are the following:

1. The State Audit Office controls the appropriate and responsible management of assets belonging to public finances according to the law on public finances. Since the assets transferred to the public boards belong to public finances, the State Audit Office has the right to control these. Furthermore, the State Audit Office can control the whole management of the Academy and the economic chambers (not only the management of transferred assets) based on legality, expedience and successfulness.

2. The competent ministers control the respective boards legally. They see if the Basic Rules and other regulations of the boards are lawful, whether the resolutions of some organizations or officials break the law or internal rules or not. The minister can go to court and the court can suspend the operation of the board in case of violation of the law and can assign a supervisor to the public board. The court cannot liquidate the public board. The situation is different in the case of mountain municipalities because the court can dissolve the mountain municipality at the minister's request. In this case the municipality has to be re-established within 60 days. If the same thing happens within 5 years, the winegrowing area classification automatically ends.

3. The laws on each public board order the establishment of a mandatory internal control organization. This organization should control the given board and ensure the legal operation.

4. Some laws order that from time to time an independent CPA must check the management of the public board. 
Ad6. The concepts of indebtedness and insolvency

There is no mandatory law on this. This question has not been raised so far in Hungary, maybe because there has not been any situation that would have made it necessary. (I would note here that in the case of local self-governments the rules of debt arrangement procedures have been made only in 1996, while the law on local self-governments was issued in 1990) In my opinion insolvency regarding public boards means that the board is unable to perform its obligation of payment within the given period of time. The deadline is always determined by the specific contract or the invoice written based on the contract.

\section{Ad7. The question of permanent insolvency}

There is no specific law on this, nor any legal definition of permanent insolvency. Who should make what steps in case of permanent insolvency can be answered as follows:

- first of all the officials and organizations of the public board must make the necessary steps to rehabilitate the financial balance (reducing expenses, selling mobilized assets, taking out credits etc.),

- the creditors have the right to help (but it is not mandatory), for example by rescheduling the debt or reducing the claims,

- theoretically the Parliament, which establishes public boards, is entitled to help by modifying the law on budget or giving budget subsidies.

These possibilities do not exclude one another. The supervising minister has limited possibilities as I mentioned at question 5. The minister can only emphasize the importance of keeping the laws. If this is not successful, the minister can go to court.

\section{Ad8. Can the creditors ask for bankruptcy proceeding, liquidation? \\ If not, what possibilities the creditors have?}

As I mentioned in the chapter on local self-governments, bankruptcy proceeding or liquidation can be initiated only against economic companies. It cannot be done in case of public boards. Debt arrangement procedures cannot be initiated here either. If the public board becomes insolvent, and cannot pay off the debts, then it is responsible with its whole assets. It can attempt to sell its free assets, reduce the expenses or take out credits or have the debt rescheduled. If they cannot pay off the debt after all these steps, the creditor can go to court according to the civil law and can ask the court to oblige the public board to pay off the debts. If this happened and the board does not pay, the court will execute distress. When doing this, it is not possible to dissolve the public board. The only exception is the mountain municipality 
from the court. If they cannot pay off the debt, they operate illegally. If the legal operation cannot be rehabilitated, the minister can ask for the dissolution of the municipality. The creditors cannot enforce their claims against the Parliament that established the public board by law as there is no legal possibility to do this.

Ad9. Is the state responsible for the debt?

The Act does not regulate this question, but based on the regulations, it can be deduced that the state is not responsible. The Civil Code states that the rules on associations are to be applied to public boards. In case of associations the law excludes the responsibility of the state. The association itself is responsible for the debts with its assets and the members are not responsible for the debts beyond the membership fees. The second part of this question mentioned in chapter 3 does not have any sense in this case, since the public boards are legal entities.

Ad10. Can those creditors initiate a trial who have not been paid off?

The answer is the same that I wrote down in case of the local self-governments. Briefly: yes, theoretically the creditors can initiate a trial according to the Civil Code against the persons or organizations controlling the public board. There have been no such cases so far in Hungary.

\section{Ad11. The question of transferring tasks to private organizations}

This question is only theoretical, since the state has established the public boards to carry out the public tasks recorded by law. However, it cannot be excluded theoretically that the state transfers the public tasks to private organizations, economic companies. In this case there are different rules of responsibility. These are the Civil Code rules of bankruptcy proceedings, liquidation and final settlement. This could happen if the Parliament trusted a minister who can establish an economic company or can obtain concern based on the law on public finances to carry out the task. This would be possible only with the permission of the Minister of Finances. A further restriction would be that the liability of the state in the established economic company could not exceed the extent of asset contribution. Another restriction would be whether the performance of the public tasks by the public board makes business like economic activities necessary or not. The prerequisite of establishing economic companies is the performance of businesslike economic activities. It must be made clear that if the state transferred the performance of public tasks to private organizations, the state would not be responsible for the debts as it is not responsible in the case of public boards. 
Ad12. The question of initiating criminal procedures

The answer is the same that I gave in the case of local self-governments. Briefly: yes. Reports can be made in case of suspecting crime and the Criminal Code contains several crimes and punishments for those who commit such crimes.

\section{The third type of public institutions: the public foundations}

\subsection{General informations about public foundations}

According to the Civil Code a public foundation is a foundation that is established by the Parliament, Government or local self-government to carry out public tasks. A public task is a state task or local self-government task that must be carried out by the state or the local self-governments based on the law. The establishment of a public foundation does not concern the performance of public tasks by the state and the local self-governments, so the public foundation does not replace the state, nor the local self-governments. On the other hand, the state (local self-governments) are obliged to pay attention to the operation of public foundations and if the foundation does not carry out the tasks properly, they must take steps immediately. The establishment of a public foundation happens when a Foundation Charter is issued. The charter must indicate the organization of the foundation, its headquarters, its goals, the assets attributed to the accomplishment of the goals and the way of utilization, the trustee and the organization entitled to control the trustee. The Founding Charter must be issued in an official gazette.

If the law does not order differently, anyone can join the public foundation. The Charter may prescribe that the trustee's approval is necessary if someone wants to join the foundation. Assets must be provided for the foundation so that it can accomplish its goals. The Foundation is established when it is registered by the court and it ceases to exist when it is canceled from the registry. It is the founder who hands in a request of establishment to the court. The Founding Charter must be attached to the request. The court examines if the assets necessary to accomplish the goals exist, if the assets are enough to start the operation and they are proportional to the performance of the public tasks. The trustee manages the assets of the foundation according to the Founding Charter. The trustee is subjected to inform the founder of the management every year and is subjected to publish other major data as well. The trustee is continuously controlled by the controlling organization established by the Founding Charter. The legality 
and expedience is controlled by the State Audit Office. The legal supervision is carried out by the prosecutor's office. The prosecutor examines if the foundation operates per the law and the Founding Charter. If the legality of operation cannot be ensured in any other way, the prosecutor goes to court. The court gives a deadline to the foundation to end the illegal conditions and rehabilitate the legal operation. If this is not successful, the court dissolves the foundation and orders its cancellation from the registry. The court dissolves the foundation based on the prosecutor's request if the accomplishment of goals has become impossible for any reasons. Finally, the court can dissolve the foundation at the founder's request if the need for the given public task has ended or there is a more effective way of performing the task. In case of dissolution the assets of the foundation-after the payoff of creditors-goes to the founder with the following restriction: the assets must be used for similar goals. The public foundation is a legal entity. It is responsible for the debts with its own assets.

Since the establishment of the public foundation happens with the issue of a Founding Charter, the specific regulation of goals, organizational structure and management cannot be uniform, as in the case of the public boards. That is why there are no uniform answers to the 12 questions. I will try to refer to the differences.

\subsection{Answers to the raised questions}

Ad1. The income of public foundations, taking out credits

A public foundation is an attribution of assets for public purposes. The founder is obliged to provide starting assets to the public foundation, the assets must be enough to start the operation and must be proportional to the magnitude of the task to be carried out. So here there is a considerable attribution of assets at the beginning - opposed to the public boards. The resources during the operation are less important here. The public foundation can be open or closed. It depends on the fact whether the Founding Charter allows new members to join or not. If yes, one of the resources of income is the contribution paid by the joining members. The further resources are usually the following:

- the avails of the founding assets,

- the contribution accepted in the budget,

- donations, contributions,

- offers from personal income taxes.

(An interesting thing is that the Miklós Wesselényi Sports Foundation carrying out public tasks related to sports gains income from the taxes of 
drawing games (12\%) and from the taxes of pools (100\%) as a regular and normative income.)

If the management makes it necessary, the foundation can take out credits, except when the founder forbids this in the Founding Charter.

Ad2. The procedure of taking out credits

There are no legal restrictions, but the Founding Charter can contain restrictions or it can contain proper procedures regarding the credits.

\section{Ad3. Deposit}

There is no mandatory law, so the deposit is a subject of free agreement between the creditors and the foundation.

\section{Ad4. The extent of indebtedness}

There is no law, but the Founding Charter can contain restrictions. The general principles of "normal management" are of course valid for the management of public foundations as well, so the public foundation must manage so that it can carry out its public tasks. The Founding Charter usually expressly records that the public foundation manages according to a yearly budget (financial plan). This must keep the expected incomes and expenses in balance. This is the trustee's responsibility.

\section{Ad5. Control}

There are no regulations that expressly prevent getting in debt. The state tries to prevent irresponsible management through external and internal control. The forms of these are the following:

a) The State Audit Office controls the legality and expedience of the public foundations' management.

b) The prosecutor has a general legal supervision over the whole operation of the public foundations. If the legal operation is not ensured for any reason (including possible indebtedness), or the accomplishment of the goals determined in the Founding Charter has become impossible, the court will dissolve the public foundation at the prosecutor's request.

c) The founder is obliged to assign not only a trustee, but also a controlling organization of the trustee in the Founding Charter. The controlling organization (usually a Supervising Committee) has the job of controlling the whole operation and management of the public foundation. If necessary, the controlling organization informs the founder once a year of the management and operation. 
d) Every year an independent CPA examines the management of the public foundation and uses the results in the yearly report that is sent to the founder.

Ad6. The concepts of indebtedness and insolvency

There is no law on this. In my opinion indebtedness or insolvency means that the public foundation is unable to pay within the given deadline. In this case they must try to rehabilitate the financial balance or the goals written down in the Founding Charter cannot be accomplished. If this happens, the court will dissolve the public foundation at the prosecutor's request.

\section{Ad7. The question of permanent insolvency}

There is no specific law on this, nor any legal definition of permanent insolvency. Who should make what steps in case of permanent insolvency can be answered as follows:

- first of all the trustee of the public foundation must make the necessary steps to rehabilitate the financial balance (reducing expenses, selling mobilized assets, taking out credits etc.),

- the founder theoretically has the right to help (but it is not mandatory) rehabilitate the financial balance, since the founder is responsible for the performance of public tasks,

- the creditors have the right to help (but it is not mandatory), for example by rescheduling the debt or reducing the claims.

The prosecutor's office who does legal supervision does not have the possibility to rehabilitate the balance of management, they go to court when they notice that the law was broken.

These possibilities do not exclude one another.

Ad8. Can the creditors ask for bankruptcy proceeding, liquidation?

If not, what possibilities the creditors have?

The answer given in the case of public corporations can be repeated here with one difference: if the legal operation is not ensured, the accomplishment of goals determined in the Founding Charter become impossible (even because of indebtedness), the prosecutor can ask the court to dissolve the public foundation. The creditors cannot enforce their claims against the founder because they do not have any legal possibility to do it. The creditors can go to only the prosecutor, who can state the illegal operation and can initiate a trial for dissolution. 
Ad9. Is the state responsible for the debt?

The law does not regulate this question, but based on the regulations, it can be deduced that the state is not responsible. Why? The Civil Code states in the rules on public foundations that in the case of issues not regulated, the rules on foundations are to be applied. In the case of foundations the Civil Code states that the rules on the management of associations are to be applied to the management of foundations. As I mentioned earlier, the association itself is responsible for the debts with its own assets. Again I need to mention the rule which states that the establishment of public foundations does not concern the performance of public tasks in the case of the state (local self-governments). If the public foundation is unable to carry out the public tasks due to insolvency or any other reason, the state (local self-government) as the founder must take steps immediately. It is not really important what they do (transfer the tasks to state administration organizations, establish management organizations etc.). The main point is that the public tasks must be carried out. The second part of this question mentioned in chapter 3 does not have any sense in this case, since the public foundations are legal entities.

Ad10. Can those creditors initiate a trial who have not been paid off?

The answer is the same that I wrote down in case of the local self-governments. Briefly: yes, theoretically the possibility initiating a trial exists. There have been no such cases so far in Hungary.

\section{Ad11. The question of transferring tasks to private organizations}

The main point of the answer is the same I gave in the case public corporations. The theoretical possibility of transfer exists and of course there are different rules of responsibility. Since the restrictions mentioned in the case of public boards exist here as well, the transfer is really theoretical. As regards the final responsibility of the state, the situation is the following as in the case of public boards. The state is not responsible for the debts of public foundations. It is responsible for the performance of public tasks. The way how the state solves this task is their business: it can trust state administration organizations, local self-governments, can establish public corporations etc.

\section{Ad12. The question of initiating criminal procedures}

The answer is the same that I gave in the case of local self-governmentss. Briefly: yes. Reports can be made in case of suspecting crime and the Criminal Code contains several crimes and punishments for those who commit such crimes. 


\section{Public utility companies}

In chapter 2 I wrote that public institutions are such organizations that were established by the state to carry out public tasks. These organizations have autonomy. Examples: local self-governments, public corporations and public foundations.

However the Civil Code names and regulates public utility companies as legal entities. I think I need to mention them because of the following:

A public utility company is a legal entity that can be established and operated by anyone (individuals, legal entities, the state, the local self-governments etc.) according to the rules of private law, based on the law on economic companies. The peculiarity of public utility companies is that they do so called public utility activities and maintain businesslike economic activities to promote this public utility activity and the profit cannot be divided among the members. The rules on limited liability companies are to be applied to the operation of public utility companies and they must establish a Supervising Committee and they have to choose a CPA. The rules on company law and bankruptcy law are to be applied in case of the winding-up of public utility companies. There is a difference: the assets remaining after paying off debts must be used for public utility purposes.

The public utility activity carried out by a public utility company is an activity that satisfies the common needs of society without gaining profit or assets. Examples: helping families, education, protection of the nature, voluntary fire-fighting, protection of the environment, protection of human rights etc. As you can see, the public utility companies operate as non-profit organizations according to the rules of private law. They can be established either by the state or others to carry out public utility tasks. They do not carry out public tasks, but public utility tasks and they do not operate according to the rules of public law, but they are established and wind up according to the rules of private law. That is why I did not listed these organizations among the public institutions (local self-governments, public boards and public foundations) and I think it is not necessary to answer all the 12 questions in the case of public utility companies.

\section{The public utility organizations}

The Parliament passed a separate law on the so called public utility organizations (Law No. CLVI of 1997) to make the operation and management of these non-governmental, non-profit organizations clearer and to promote 
their public service activities. The law determines the types of public utility activities in 22 points. I have already referred to these in the preceding chapter. These organizations can ask the court to be registered in the public-utility registry. If this happens, these organizations will have exemption from company tax and also allowances regarding local taxes, duties and dues and personal income tax. Only the following types of legal entity organizations can apply for registration:

- social organizations (except for political parties, organizations representing interests, insurance companies),

- foundations,

- public foundations,

- public utility companies,

- public corporations (if the establishing law allows it).

The Tax Authority controls the public utility organizations regarding taxes, the State Audit Office controls the utilization of subsidies from the budget. The legal control is done by the prosecutor's office. The prosecutor can ask the court to cancel the given legal entities from the registration if the organization operates illegally in spite of the official warning. If the yearly income of the organization exceeds five million HUF, a supervising board must be established even if there is no such obligation. This supervising board controls the operation and management of the organization. In case of illegal operations, they call for winding-up, finally they inform the prosecutor. The public utility organizations must keep separate records of incomes and expenses that come from the public utility activities and the enterprises. The incomes of public utility organizations are the following:

- contributions received from the founder or some sub-systems of public finances or other donations that must be used for public utility purposes,

- the income from the public utility activities,

- the income from the investment of means,

- membership fees,

- income from the enterprise,

- other income.

The public utility organizations cannot issue bills or bonds embodying credit relations and with the exception of public utility companies, they cannot take out credits endangering the public utility activities. They cannot use the contributions received from the different sub-systems of public finances to pay off credits, nor to cover credits. It is a major rule that the public utility organizations cannot divide the incomes coming from the management activities, they must use it for the goals determined in the Founding Charter. It can be stated from the above mentioned facts that the declaration of an 
organization as a public utility organization is not relevant regarding our subject. Since the activities accomplished by these organizations are peculiar, I think the most important rules related to these organizations need to be presented, avoiding the answers to the 12 questions.

\section{Summary}

As regards the present review concentrating on the insolvency of public institutions, it should be stated that the Hungarian legal system responded relatively quickly to the political changes in 1989-1990. The legal system has created the legal institutions and their conditions of operation that are necessary to reduce the exaggerated overtaking of tasks on the part of the state. I believe these legal institutions operate pretty well, however not perfectly and the Hungarian state administration of 2001 is considerably "smaller" than the state administration before 1989 and this new administration serves the citizens' interests much better. This must not make us self-conceited, but we must not be silent when talking about the results. We should continuously pay attention to the ways of performing public tasks in these of other countries, as we have a lot to learn and we have a lot to give as well. The section IV.D.1. of the 16th International Congress of Comparative Law that the present review was made for provides an excellent opportunity to do this. 